\title{
A REPRESENTAÇÃO DOS VAQUEIROS NAS IMAGENS PRODUZIDAS PELO GRUPO JORNADAS FOTOGRÁFICAS DO VALE DO SÃO FRANCISCO
}

\author{
Priscilla Maria de Souza Silva ${ }^{1}$ \\ Carla Conceição da Silva Paiva²
}

\section{Resumo:}

O Semiárido é tema de várias produções midiáticas e literárias, que retratam essa região pelo clima seco e um lugar difícil para sobrevivência, destacando apenas a seca e o sofrimento populacional como foco. Paralelo a isso, surgiram discussões sobre a Educação Contextualizada para "Convivência com o Semiárido" como ferramenta de ensino, visando benefícios sociais e pensando em políticas públicas que, realmente, estejam adequadas as características das localidades semiáridas. A partir dessa perspectiva e considerando a forma como era/é, apresentado o Semiárido pelas representações de pessoas de fora desse território e, analisando agora a visão de quem está convivendo diretamente nesse espaço, surgem outros grupos culturais, como o Jornadas Fotográficas do Vale do São Francisco, por exemplo, que por meio das suas imagens pretendem retratar uma nova cultura, tradições e história de parte desse território. Este artigo pretende analisar uma parte dessa produção imagética, especificamente, investigando como o vaqueiro é fotografado, a partir das concepções sobre análise da imagem descritas por Martine Joly (2012).

Palavras-chave: Representação, Jornadas fotográficas, Vaqueiros.

\begin{abstract}
:
The semi-arid region is the subject of several media and literary productions that portray this region due to the dry climate and a difficult place for survival, highlighting only the drought and the population suffering as a focus. Parallel to this, discussions about Contextualized Education for "Living with the Semi-Arid" emerged as a teaching tool, aiming at social benefits and thinking about public policies that, in fact, are adequate the characteristics of semi-arid areas. From this perspective and considering the way it was, the Semi-Arid is presented by the representations of people from outside the territory, and analyzing now the vision of who is living directly in this space, other cultural groups, such as the Photographic Days of the Valley of the San Francisco, for example, who through their images intend to portray a new culture, traditions and history of part of that territory. This article intends to analyze a part of this imagery production, specifically investigating how the cowboy is photographed, from the conceptions about image analysis described by Martine Joly (2012).
\end{abstract}

Key words: Representation, Photojournalism, Cowboys.

\footnotetext{
${ }^{1}$ Graduanda em Comunicação Social - Jornalismo em Multimeios pela Universidade do Estado da Bahia (UNEB), campus III. E-mail: priscillasouza-s2@ hotmail.com

${ }^{2}$ Graduada em Comunicação Social - Relações Públicas pela Universidade do Estado da Bahia (1998), mestre em Educação e Contemporaneidade pela mesma universidade, possui doutorado em Multimeios pela Universidade Estadual de Campinas (2014) e aperfeiçoamento em Intensivo de Cinema Digital pela Academia Internacional de Cinema (2012). Atualmente é Professora Adjunta da Universidade do Estado da Bahia (UNEB). E-mail: ccspaiva@gmail.com
} 


\section{Resumen:}

El Semiárido es tema de varias producciones mediáticas y literarias, que retratan esa región por el clima seco y un lugar difícil para la supervivencia, destacando sólo la sequía y el sufrimiento poblacional como foco. Paralelo a eso, surgieron discusiones sobre la Educación Contextualizada para "Convivencia con el Semiárido" como herramienta de enseñanza, visando beneficios sociales y pensando en políticas públicas que, realmente, estén adecuadas las características de las localidades semiáridas. A partir de esa perspectiva y considerando la forma como era / es, presentado el Semiárido por las representaciones de personas de fuera de ese territorio y, analizando ahora la visión de quien está conviviendo directamente en ese espacio, surgen otros grupos culturales, como el Jornadas Fotográficas del Valle del San Francisco, por ejemplo, que por medio de sus imágenes pretenden retratar una nueva cultura, tradiciones e historia de parte de ese territorio. Este artículo pretende analizar una parte de esa producción de imágenes, específicamente, investigando cómo el vaquero es fotografiado, a partir de las concepciones sobre el análisis de la imagen descritas por Martine Joly (2012).

Palabras clave: Representación, Jornadas fotográficas, Vaqueros.

\section{INTRODUÇÃO}

O Semiárido Brasileiro - SAB, com maior concentração na região Nordeste do país, é conhecido pelas representações midiáticas que criam uma imagem de seca e sofrimento atribuído às pessoas que vivem nesses locais. Em sua maioria, vemos em filmes, novelas, jornais, literatura, etc. imagens distorcidas ou limitadas do que é o Semiárido, um espaço de clima quente, que apresenta pouca mudança durante o ano; chuva em pouca quantidade e que não são bem distribuídas.

Paralelo ao que é divulgado, nessa região, curiosamente, há o maior índice de chuva do planeta, e as consequências da chuva ou da falta dela não ocorre de forma uniforme. Devido à força do sol e do vento, como também da falta de plantas e a evaporação, surge à necessidade de construir lugares que reservem essa água. (RESAB, 2004)

Essas contribuições são fruto dos discursos que começam a aparecer relacionados ao Semiárido a partir de uma outra visão, a perspectiva da convivência, que trazem agora um olhar de quem presencia as mudanças do clima nesse espaço e sabe das reais dificuldades encontradas em uma região semiárida. Uma proposta que pensa não o "combate à seca", mas a "Convivência com o Semiárido" que tem a liderança de movimentos sociais, setores da Igreja Católica e organizações internacionais não governamentais. Para Carvalho (2011), essas contribuições pensam “(...) criticamente na invenção do passado para a construção da História Oficial, questionando tais narrativas, e nesse exercício trazer outros ângulos" (p.14). 
Nesses estudos, voltados para a convivência, nota-se que existem semiáridos plurais, levando em conta não só a oferta de água como outras características também essenciais para a determinação desse clima.

(...) não existe um único território Semiárido, pois do ponto de vista de sua cartografia, este território é demarcado por fronteiras muito fluidas, que atendem aos diferentes interesses dos atores sociais, das leis e agencias de desenvolvimento em vigor, bem como, das próprias compreensões sobre as características da natureza semiárida (CARVALHO, 2011, p.19).

A lógica da convivência também agrega abordagens diferentes de acordo com locais específicos, considerando que é preciso pensar formas adequadas para viver nesse meio, no longo prazo, visando melhorias e desenvolvimento. Conviver passa a ser, portanto, um outro modelo de relação do homem com a natureza, que busca formas alternativas de "sobreviver" de acordo com cada local. As ações, agora condizentes com a região, ajudam os moradores a 
obter mais vantagem do que possuem e o incentivo a captação de água da chuva é um bom exemplo de aprendizado ligado a essa lógica da Convivência com o Semiárido.

Para tanto, faz-se necessário aprender e ensinar diversos saberes locais como também universalizar práticas já desenvolvidas por alguns segmentos dos movimentos sociais. Assim, também surgiu a Educação Contextualizada para a Convivência com o Semiárido - ECSAB, que é uma nova forma de educar, compreendendo que é preciso ver e viver nesse espaço visando os seus limites e capacidades. Nesse sentido, a contextualização da educação busca relacionar o conhecimento a realidade.

(...) a contextualização é um processo facilitador da compreensão de sentido das coisas dos fenômenos e da vida, enfatizando informações que o estudante tem e encorajando a busca de novas informações a partir dessas. Enfim, contextualizar implica problematizar o objeto de estudo a partir dos conteúdos, dos componentes curriculares, fazendo a vinculação com a realidade, situandoos no contexto e retornando com um novo olhar (CARVALHO,2011, p. 24)

Assim, as pessoas inseridas nesse contexto vão poder aplicar o que aprendem buscando melhorias nas condições de vida de acordo com o seu espaço.

Nesse contexto, as discussões com pessoas de todas as idades sobre a Convivência com o Semiárido ajudam a conscientizar a todos sobre "(...) a falta de políticas públicas apropriadas para o Semiárido, considerando seu povo, sua história e seu clima" (CARVALHO, 2013, p. 20), bem como a identificar o que precisa ser melhorado para afetar o saber, a cultura, a tecnologia e os procedimentos usados pelas pessoas dessas localidades. Defende-se que com ações adequadas, a qualidade de vida e a permanência nesses lugares são mais viáveis, principalmente, abolindo a necessidade que alguns moradores tinham de sair da sua terra para procurar meios de sobrevivência em outras regiões, fato comum durante a década de 1980, quando essas pessoas iam para o Sudeste do país.

Esse processo de migração era comum, em um Nordeste, como descreve Albuquerque Júnior (1999), no livro "A invenção do Nordeste", baseado na tradição e na saudade. Ele destaca que o modo político como a região é vista, mostrando algumas alternativas dadas pelo governo que não supriam as necessidades do povo de acordo com as características da região colaborava ainda mais para essa prática. 
No segundo capítulo do referido livro, a abordagem do Nordeste como "Espaço da Saudade" mostra a forma estereotipada que essa região é relatada nas várias obras brasileiras de diferentes seguimentos, como o cinema, o jornalismo, a música e a literatura. Afirmando que "O nordeste dos 'regionalistas e tradicionais' é uma região formada por imagens depressivas, de decadentes, como os presentes nas obras de José Lins do Rego. Imagens evocativas de um passado de tradição que estava se perdendo." (p. 80), Albuquerque Júnior deixa evidente como os estereótipos ajudam não só a firmar esse conceito de passado sobre o Nordeste, mas influência também na construção do futuro.

A memória tradicionalista nada mais é que a "vontade de prolongar o passado para que o presente e, quem sabe, fazer dele também o futuro" (ALBUQUERQUE JÚNIOR, 2003, p.

81). Sendo esse um espaço considerado apenas para uma volta as raízes, para que as pessoas que foram "obrigadas" a sair da sua terra para "sobreviver" possam visitar e manter as suas lembranças.

Essas características colaboraram também para a construção de alguns personagens como típicos representantes dos nordestinos, por exemplo, o vaqueiro. Assim, mesmo sendo comum em outras áreas do Brasil, a representação do vaqueiro sempre é ligada ao Nordeste. Apresentado nas produções como rude, forte e resistente, por exemplo, o vaqueiro é agigantado e ao mesmo tempo tratado como desajeitado nessas narrativas, uma "figura associada umbilicalmente ao sertanejo" (ALBUQUERQUE JÚNIOR, 2003, p. 211).

Considerando essas questões, este artigo apresenta uma análise das imagens dos vaqueiros registradas na saída $75^{\circ}$ do Grupo Jornadas Fotográficas do Vale do São Francisco, realizada no dia 17 de dezembro de 2017, disponível no site do referido coletivo. Para tanto, utilizou como procedimento metodológico a análise de imagem a partir da perspectiva de Martine Joly (2015), que defende uma abordagem racional da imagem, ajudando os espectadores a entender melhor a fotografia como forma de comunicação e como ela pode transmitir mensagens, de acordo com os nossos conhecimentos.

\section{Jornadas Fotográficas do Vale do São Francisco: outra visão do Semiárido}

A fotografia é um dos meios mais fieis de retratar uma realidade. Expressa por meio dela cultura, costumes, espaços e ideologias que já se tornaram uma prática comum, uma representação. Com essa visão, surgiram grupos produtores de imagens com o intuito 
mostrar as experiências dos seus locais de convívio. Um exemplo disso é o Jornadas Fotográficas do Vale do São Francisco, que, por meio de um blog oficial, expõe os resultados de saídas fotográficas em busca de registros em eventos ou lugares importantes para a representação da região.

O grupo é uma iniciativa de Marcus Ramos, paulista, professor da Universidade Federal do Vale do São Francisco - UNIVASF, que convidou alguns amigos para fotografar alguns locais que chamavam atenção na cidade. "A Parada da Diversidade" que aconteceu em Petrolina-PE, em 2010, foi à primeira saída do grupo. Os encontros ocorrem desde então com o intuito de valorizar o povo e as culturas do Vale do São Francisco, mas partindo de análises feitas com a ajuda de algumas obras sobre as representações culturais da região Semiárido e alógica da Convivência, surge à necessidade de investigar se, de fato, esse objetivo do grupo está sendo alcançado.

Para Denise Jodelet (2001): "Quanto mais gerais são as interpretações, mais especulativas e menos fiéis são as representações mentais ou públicas particulares de que fazem a síntese." (p. 99). Por isso, a importância de se estudar as representações sociais, buscando uma imagem coletiva mais adequada para as pessoas de cada contexto. A maneira como é transmitida cada representação conta muito sobre as formações de pensamentos relacionados a um determinado espaço, assim "As mutações são fenômenos certamente importantes, mas raros. Ao contrário, as representações tendem a ser transformadas, mais do que reproduzidas exatamente, cada vez que são transmitidas." (p. 100), por isso precisam acontecer de forma consciente. 


\section{As representações dos vaqueiros no Jornadas Fotográficas}

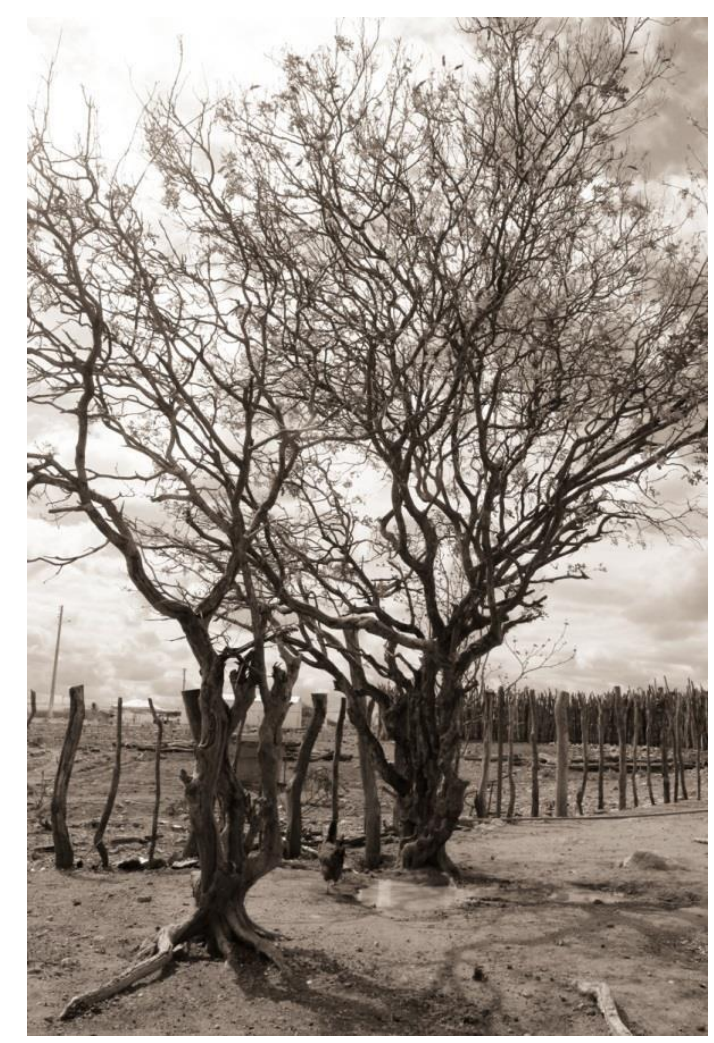

Figura 1 - Produção de GUSTAVO MATOS

A primeira imagem (Figura 1) selecionada para a análise não registra a presença do personagem nordestino em análise, mas em seu enquadramento mais fechado, sombras quentes e contrastes bem marcados, é possível indicar uma visão do fotógrafo, a partir do que aponta Joly (2012): "interpretar uma mensagem, analisá-la, não consiste certamente em tentar encontrar ao máximo uma mensagem preexistente, mas em compreender o que essa mensagem, nessas circunstâncias, provoca de significações" (p. 44). O vaqueiro não aparece, contudo, pode-se observar o local onde, normalmente, registra-se culturalmente sua atuação.

A imagem apresentada tem as características, normalmente, descritas para denominar a região semiárida enquanto sertão, o que alguns autores denominam de Sertão semiárido. A foto em sépia, tom usado para escurecer cores como amarelo e marrom, remete ao passado, atribuindo um caráter de envelhecimento, sempre usado para fazer relação com outra época, quando se representa o Nordeste. O enquadramento fechado é, normalmente, usado para centralizar um único objeto na composição, contudo na Figura 1, pode-se observar mais de um elemento centralizado na composição das massas, duas árvores e o cercado de uma propriedade rural. Ao compor a foto com galhos e sombras, Gustavo Matos parece se remeter a outras imagens de seca já presente no imaginário e nas mídias e o sentimento de que 
esse lugar é sempre denominado de alguma forma como sem vida, fato acentuado pela presença de um único animal, uma galinha que no jogo de luz e sombras, fica "camuflada" entre as duas árvores, quase não aparecendo.

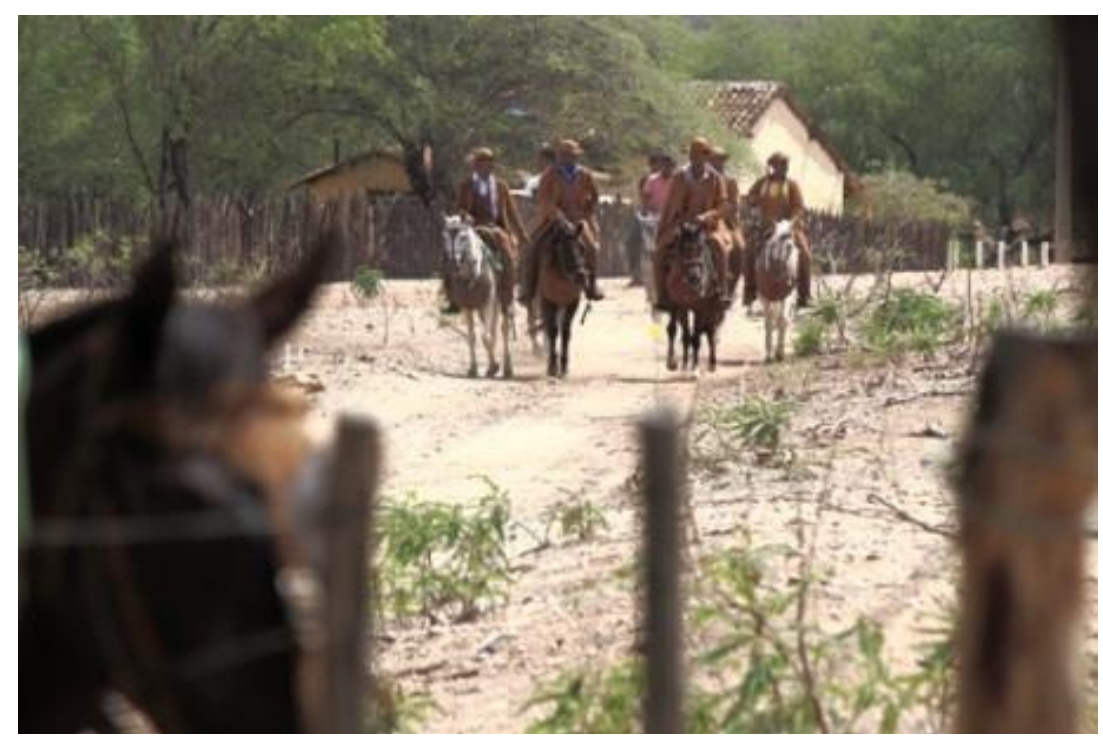

Figura 2 - Produção de GUSTAVO MATOS

A segunda imagem analisada (Figura 2), com tons de verde, marrom e branco, agrega uma mistura de sensações representadas por essas cores. O verde, em último plano, transmite a sensação de abundância, e contrasta com os tons de marrom que aparecem nos planos à frente, que faz lembrar "passado nordestino", associado sempre à melancolia. O branco é um pouco mais alarmado na imagem devido à forma como a luz foi distribuída na fotografia, mesmo sendo, vista como uma cor que representa pureza e simplicidade, associado à luz faz perceber mais que isso, o tom estourado reflete a falta de algo, que por ser sertão é atribuído a falta de vida, nesse espaço, e que faz associação ao sol forte e solo seco.

Na composição da Figura 2, nota-se ainda que o assunto ficou no plano do meio, o objetivo é deixar centralizado e evidente os vaqueiros em meio a caatinga, como sendo uma cena comum da região. Esse tipo de composição, com o uso do tom marrom em primeiro plano, tendo uma cor parecida com o objeto central os trajes dos vaqueiros, traz a sensação de complemento, já fazendo pensar no vaqueiro como personagem típico do sertão desde o passado. O verde, como último plano, agrega uma imagem que normalmente não é comum para representação desse espaço, assim como aparece também em outros planos, mesmo quando próximo ao assunto.

Com o ângulo usado para composição, os vaqueiros ganham ainda mais destaque, visto que o primeiro plano, o cercado e o segundo plano, a cabeça do cavalo, estão desfocados levando o olhar do espectador direto para os protagonistas da imagem. 


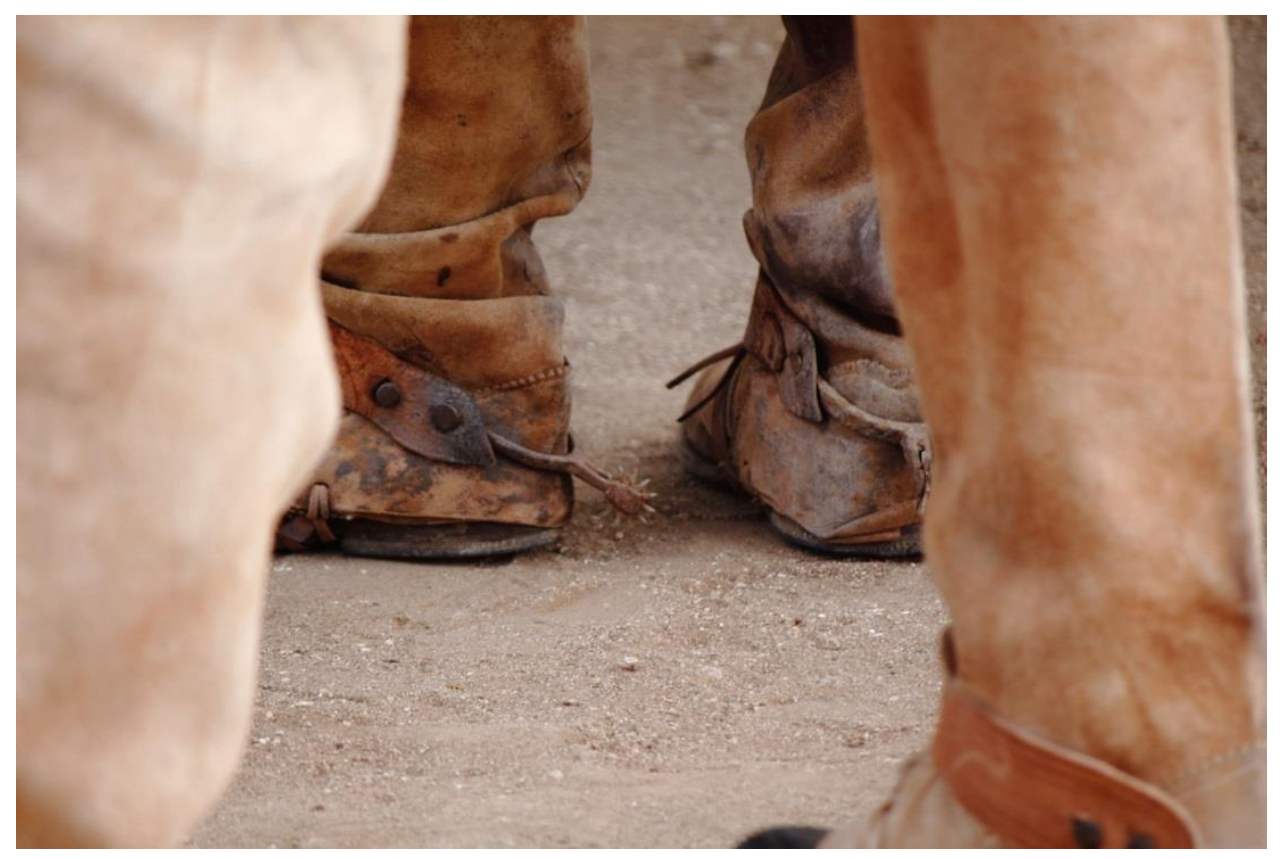

Figura 3 - Produção de GUSTAVO MATOS

Uma foto em close up é assim que a Figura 3 se apresenta, com o intuito de dar detalhes dos trajes usados pelos vaqueiros, reforçando a simbologia de personagem tradicionalmente característico do Semiárido. Segundo Joly (2012), tem-se um signo que "pode constituir um ato de comunicação quando é destinado intencionalmente (uma saudade, uma carta) ou me fornecer informações". Simplesmente porque aprendi a decifrá-lo (uma postura, um tipo de roupa, um céu cinza) (p. 33).

A Figura 3 está em ângulo normal, a foto foi retirada na altura da câmera, com um enquadramento dentro do outro, ou seja, o fotógrafo colocou o assunto em segundo plano e o desfoque do primeiro plano forma um outro enquadramento. Tanto o primeiro quanto o segundo plano trazem o símbolo das vestes dos vaqueiros, uma imagem a muito tempo construída pela mídia. Joly (2012) fala da imagem fabricada e registrada, mas ambas como forma de representação.

Não se deve esquecer, que, se qualquer imagem é representação, isso não implica que ela utilize necessariamente regras de construção. Se essas representações são compreendidas por outras pessoas além das que a fabricam, é porque existe entre elas um mínimo de convenção sociocultural, em outras palavras, devem boa parcela de sua significação a seu aspecto de símbolo, segundo a definição de Peirce (p. 40). 
Desse modo, o símbolo, mesmo criado, já é comum e se comunica com os espectadores, que pelo uso do imaginário o reconhece como característica do lugar, mas que precisam de uma representação mais adequada.

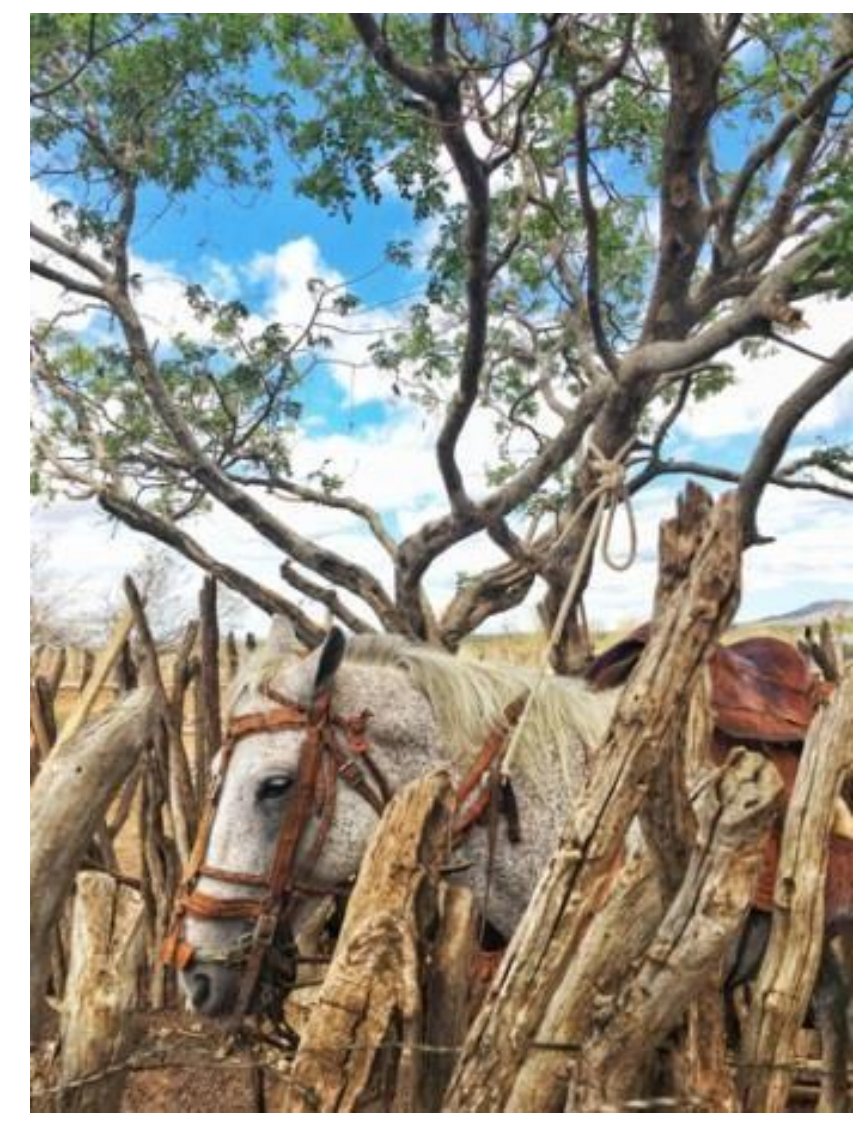

Figura 4 - Produção de JANNIFER LEE PALMER

Em sua produção, a fotógrafa Jannifer Lee Palmer, autora da Figura 4, por sua vez, utilizou o enquadramento mais fechado, destacando o cavalo, muito utilizado pelo vaqueiro, como objeto central na regra dos terços, porém deixou um pouco de espaço na imagem para o céu. Uma forma de representação poucas vezes vista pela variação de cores apresentadas. A fotografia foi retirada no plano normal (na linha do olho), deixando em evidencia também a árvore que apesar dos tons de cinza dos galhos, dar o seu destaque para o tom verde das folhas.

Ressalta-se que tanto a Figura 4 como a 5 trazem mais cores consideradas com as anteriores, dando a sensação de que, na sua edição, foi usado o modo HDR, que destaca mais as cores da imagem. Os tons de verde, relacionados à natureza e representados em abundância, transmitem a esperança de que, nesse espaço, haja vida e o azul que, na maioria das vezes, não prende tanto a atenção, ligado a região semiárida, oferece um sentido de leveza, já que o céu não está com o sol tão forte a ponto de deixar a luz da foto estourada. 
Além dessas cores, mesmo quando é retratada a vida daquele local, ainda se nota a presença de alguns tons clássicos como o marrom, presente em quase todos os planos como o cercado, os detalhes dos acessórios do cavalo, a terra que aparece ao fundo, que remete a falta da vegetação. Essas duas últimas fotografias analisadas (Figura 4 e 5) faz pensar como a representação formada sobre esse espaço, mesmo quando possuí tons mais fortes, temperatura mais fria, e variadas cores, ainda carrega características estereotipadas.

A textura das duas imagens (Figura 4 e 5) transmite ainda a impressão de que podem ser tateáveis, isso acontece devido a qualidade da imagem que nos dar a sensação de uma terceira dimensão, quando a cena tem uma marcação visível quanto a luz e o contraste, por exemplo.

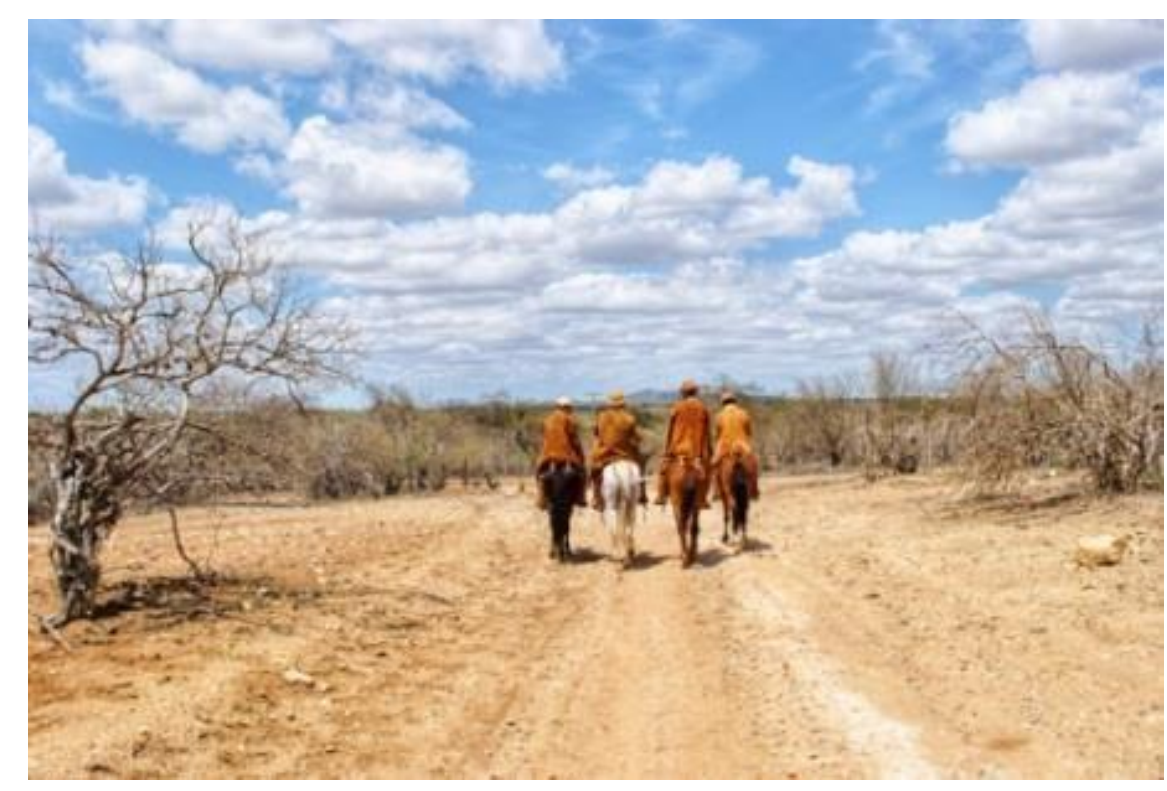

Figura 5 - Produção de JANNIFER LEE PALMER

Ainda é importante destacar que, em seu enquadramento largo, a Figura 5, feita na horizontal, passa a sensação de descanso ou estabilidade. Percebe-se que o objeto central, o assunto, são os vaqueiros, que, em meio a caatinga, cavalgam, aparentemente, com mais calma, porque o movimento dos cavalos é captado pela câmera com bastante nitidez. 


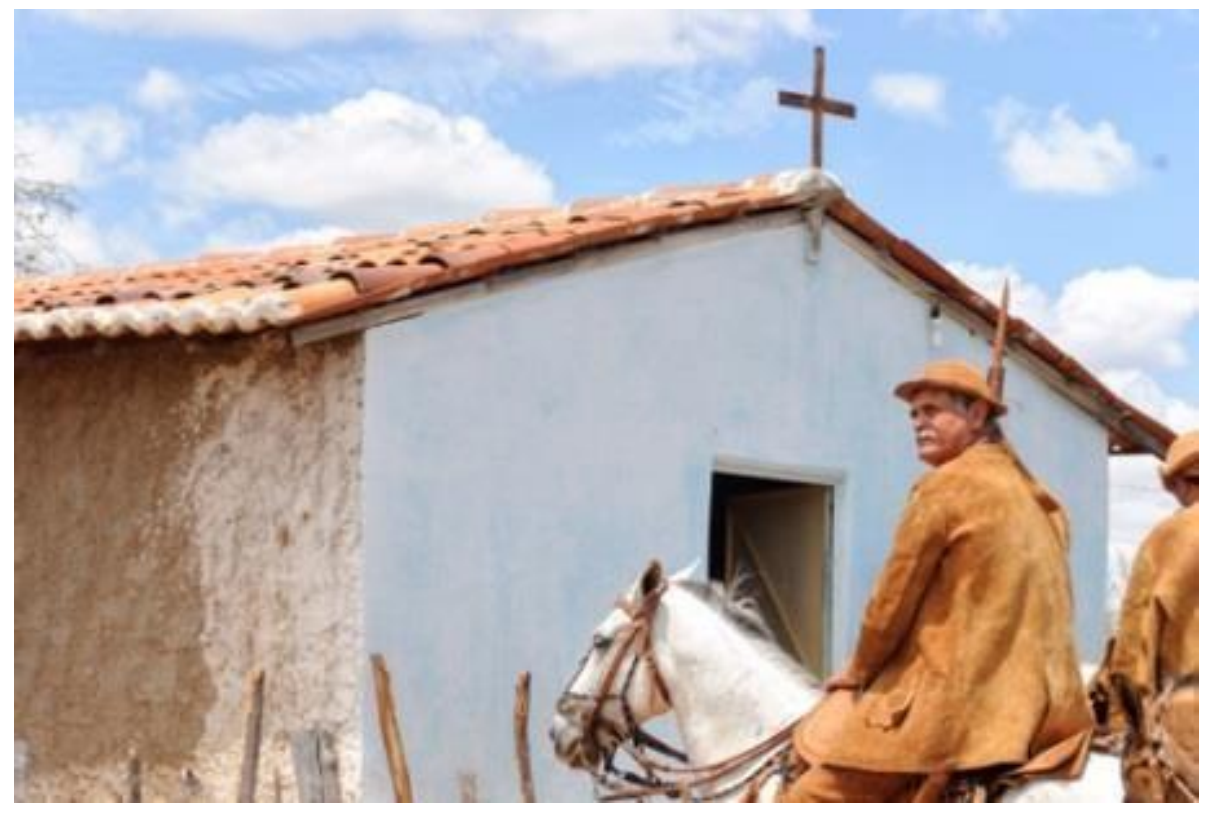

Figura 6 - Produção de JANNIFER LEE PALMER

Com o vaqueiro como assunto central em primeiro plano, a Figura 6 tem os tons presentes na maioria das fotografias feitas pelo Grupo Jornadas, quando esse personagem é o tema da saída fotográfica. Por isso o marrom é predominante devido a características das vestes do vaqueiro e do seu cavalo.

Uma representação que colabora para a afirmação do Nordeste sempre no passado, o espaço da saudade descrito por Albuquerque Junior (1999). O enquadramento na horizontal, porém mais fechado, e a existência de uma capela em segundo plano também reforçam essa significação remetendo a fé desse personagem como algo característico do sertão. 


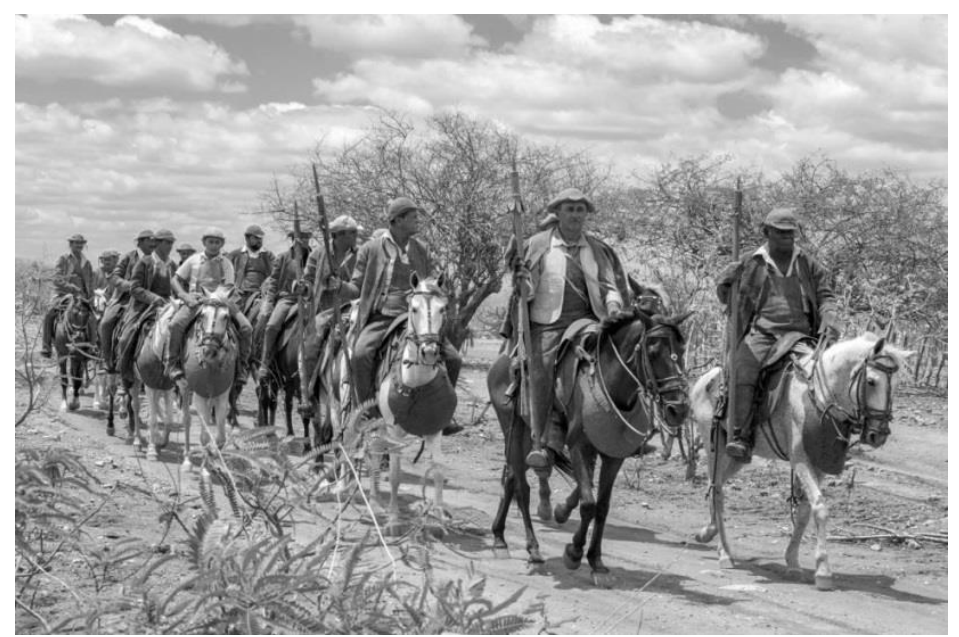

Figura 7 - Produção de MARCUS RAMOS

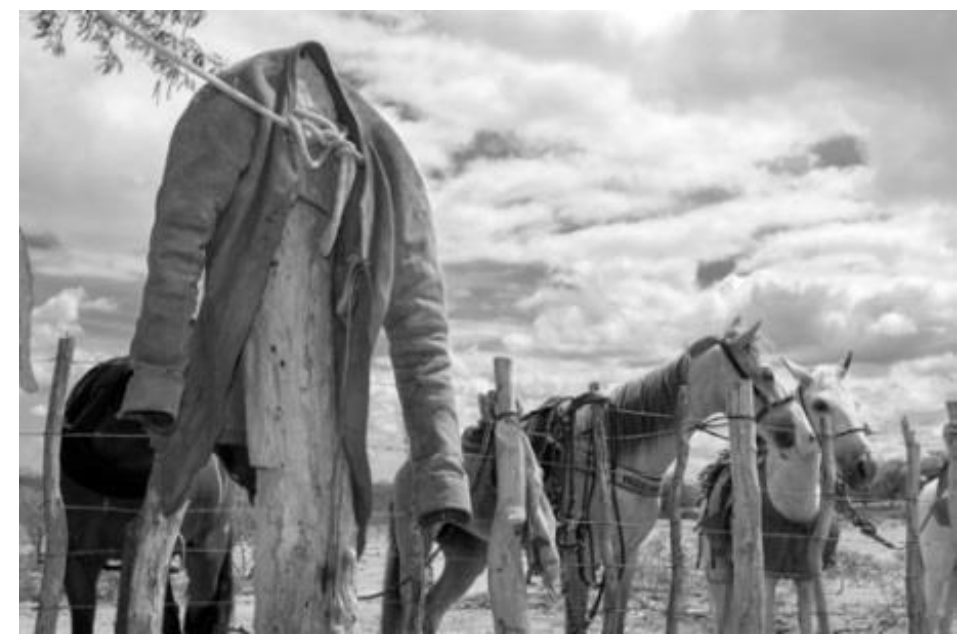

Figura Produção de 8 - MARCUS RAMOS

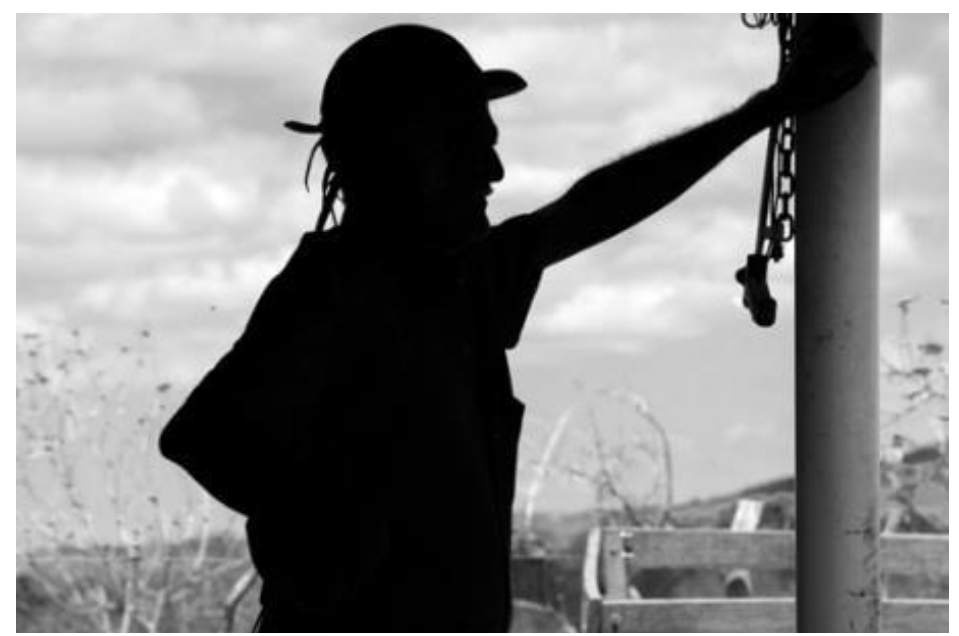

Figura 9 - Produção de MARCUS RAMOS

As Figuras 7, 8 e 9 têm aspectos parecidos, que necessariamente não estão ligados ao fato de serem imagens do mesmo fotógrafo, Marcus Ramos. As três imagens carregam uma 
edição em preto, branco e cinza. Esses são tons que logo o espectador atribui, pelo imaginário, assim como os tons em sépia, o envelhecimento, o aspecto de velho ou ultrapassado. O uso de silhueta para destaque dos acessórios, como o chapéu de couro, sempre na cabeça dos vaqueiros; enquadramentos fechados, que deixam o objeto mais ampliado; bem como a textura de contraste marcado e sombras que agregam cenários bidimensionais, o que algumas vezes pode deixar o ambiente confuso e desordenado em uma fotografia, também são características muito comuns nessas fotos analisadas.

O preto, o branco e o cinza são cores neutras e diplomáticas que, principalmente juntas, são facilmente ligadas à depressão e sentimentos relacionados à tristeza, bem como o passado. Os planos que demarcam os galhos secos e as vestes dos vaqueiros ressaltam as típicas representações sobre os sertanejos. Por fim, uma temperatura quente na edição das três imagens remete as visões criadas pela literatura, cinema, etc, de maneira geral, do que é Nordeste.

\section{Considerações Finais}

Em uma visão geral do site do Jornada e das atividades do grupo, das 77 saídas, 14 estão ligadas de alguma forma ao vaqueiro, como personagem característico do sertão. E, as fotografias de eventos culturais, como as imagens analisada aqui, destacam muitas vezes os acessórios dessa figura tida como protagonista da ideia do Nordeste como um lugar da saudade e da tradição.

Marcus Ramos, que deu inicio ao Grupo Jornadas Fotográficas do Vale do São Francisco, afirma em entrevista que "É impossível pensar em estereótipos quando se conhece um pouco melhor a região. É claro que sempre nos deparamos com aquelas imagens clássicas e perpetuadas no imaginário das pessoas (...)". Entretanto, de fato, quando o assunto é o vaqueiro encontram-se no site do Jornada várias fotografias que remetem ao que é trazido pela mídia como representação desse personagem, não podendo ignorar que, às vezes, até involuntariamente, uma imagem se torna muito presente no imaginário social sendo

quase impossível ressignificá-la. 
Segundo Joly (2012),

As imagens mudam os textos, mas os textos, por sua vez, mudam as imagens. O que lemos ou ouvimos a respeito das imagens, a maneira como a literatura, a imprensa, a sinalização apropriam-se delas, trituram-nas e apresentam-nas determina necessariamente a abordagem que fazemos delas (p. 131).

Assim, a construção de um novo imaginário precisa de modificações de acordo com a nossa realidade, por meio de novos estudos e análises que, quando levadas para prática possam desmistificar os textos e imagens divulgadas durante toda uma vida, só assim pode-se construir uma nova representação, mesmo que o caminho seja longo.

Nas imagens do Grupo Jornadas, apesar de existir a preocupação em ver a cultura nordestina de um outro ângulo, ainda é muito presente características e personagens como o vaqueiro, de forma tradicional, em tons cinza e contrastes marcados. O intuito do grupo é mostrar belezas encontradas nessa região e a diversidade cultural, mas a presença de um Nordeste da saudade no imaginário parece ainda contar bastante na construção das representações imagéticas desses fotógrafos.

Sendo assim, com a analise das imagens do grupo, levando em conta o que é dito por Marcus Ramos, professor de iniciativa do grupo, como finalidade de "combater estereótipos que nada contribuem para a valorização e o desenvolvimento da região" nota-se que o objetivo em criar uma representação mais adequada está em construção. 


\section{Referências}

ALBUQUERQUE JÚNIOR, Durval Muniz de. A invenção do Nordeste e outras artes. Ed. Massangana, São Paulo: Cortez, 1999.

REIS, Edmerson; CARVALHO, Luzineide; SILVA, Maria Luciana (Orgs.). Educação e Convivência com o Semiárido: Reflexões por dentro da UNEB. RESAB: Juazeiro-BA, 2013.

JODELET, Denise. Representações Sociais: Um domínio em expansão. EdUERJ, Rio de Janeiro. 2001.

JOLLY, Martine. Introdução à análise da imagem. Campinas, São Paulo:Papirus, 1996. JORNADAS, fotográficas do Vale do São Francisco. Disponível em: http://jornadasfotograficas.blogspot.com.br/.

RESAB, Secretaria Executiva. Educação para a convivência com o semi-árido: reflexões teórico-práticas. Juazeiro: Secretaria Executiva da Rede Educação do SemiÁrido Brasileiro, 2004. 